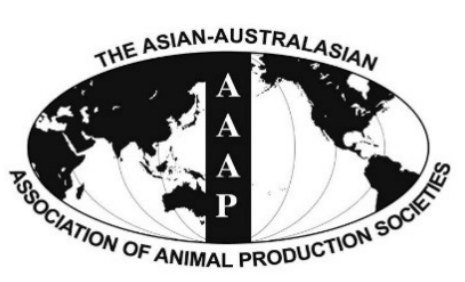

Open Access

Asian Australas. J. Anim. Sci.

Vol. 28, No. 11 : 1583-1591 November 2015

http://dx.doi.org/10.5713/ajas.15.0130

www.ajas.info

pISSN 1011-2367 elSSN 1976-5517

\title{
Effect of Lipid Sources with Different Fatty Acid Profiles on Intake, Nutrient Digestion and Ruminal Fermentation of Feedlot Nellore Steers
}

\author{
Giovani Fiorentini*, Isabela P. C. Carvalho, Juliana D. Messana, Roberta C. Canesin, \\ Pablo S. Castagnino, Josiane F. Lage, Pedro B. Arcuri ${ }^{1}$, and Telma T. Berchielli ${ }^{2}$ \\ Department of Animal Sciences, UNESP, Univ Estadual Paulista, Jaboticabal, SP 14884-900, Brazil
}

\begin{abstract}
The present study was conducted to determine the effect of lipid sources with different fatty acid profiles on nutrient digestion and ruminal fermentation. Ten rumen and duodenal fistulated Nellore steers ( 268 body weight $\pm 27 \mathrm{~kg}$ ) were distributed in a duplicated $5 \times 5$ Latin square. Dietary treatments were as follows: without fat (WF), palm oil (PO), linseed oil (LO), protected fat (PF; Lactoplus), and whole soybeans (WS). The roughage feed was corn silage (600 g/kg on a dry matter [DM] basis) plus concentrate (400 $\mathrm{g} / \mathrm{kg}$ on a DM basis). The higher intake of DM and organic matter $(\mathrm{OM})(\mathrm{p}<0.001)$ was found in animals on the diet with PF and WF (around 4.38 and $4.20 \mathrm{~kg} / \mathrm{d}$, respectively). Treatments with PO and LO decreased by around 10\% the total digestibility of DM and OM $(p<0.05)$. The addition of LO decreased by around $22.3 \%$ the neutral detergent fiber digestibility $(p=0.047)$ compared with other diets. The higher microbial protein synthesis was found in animals on the diet with LO and WS (33 $\mathrm{g} \mathrm{N} / \mathrm{kg}$ OM apparently digested in the rumen; $\mathrm{p}=0.040)$. The highest C18:0 and linolenic acid intakes occurred in animals fed LO $(\mathrm{p}<0.001)$, and the highest intake of oleic $(\mathrm{p}$ $=0.002)$ and $\mathrm{C} 16$ acids $(\mathrm{p}=0.022)$ occurred with the diets with LO and PF. Diet with PF decreased biohydrogenation extent $(\mathrm{p}=0.05)$ of C18:1 $n 9, c, \mathrm{C} 18: 2 n 6, c$, and total unsaturated fatty acids (UFA; around 20\%, 7\%, and 13\%, respectively). The diet with PF and WF increased the concentration of $\mathrm{NH}_{3}-\mathrm{N}(\mathrm{p}<0.001)$; however, the diet did not change volatile fatty acids $(\mathrm{p}>0.05)$, such as the molar percentage of acetate, propionate, butyrate and the acetate:propionate ratio. Treatments PO, LO and with WS decreased by around $50 \%$ the concentration of protozoa $(\mathrm{p}<0.001)$. Diets with some type of protection (PF and WS) decreased the effects of lipid on ruminal fermentation and presented similar outflow of benefit UFA as LO. (Key Words: Beef Cattle, Biohydrogenation, Microbial Protein Synthesis, Lipids, Protozoa)
\end{abstract}

\section{INTRODUCTION}

The lipid addition in ruminant diets has been used to increase energy density, improve livestock system efficiency and to generate meat quality with human health benefits. However, the supplementation of lipids (e.g., high levels) may cause negative effects on ruminal fermentation, affecting fiber digestion and dry matter intake (DMI)

\footnotetext{
* Corresponding Author: Giovani Fiorentini. Tel: +55-16-32092682, E-mail: giovanizoot@yahoo.com.br

${ }^{1}$ Embrapa, Centro Nacional de Pesquisa de Gado de Leite, Juiz de Fora, MG 36038-330, Brazil.

${ }^{2}$ Department of Animal Sciences, Instituto Nacional de Ciência e Tecnologia-Ciência Animal, Universidade Federal deViçosa, Viçosa, MG 36570-000, Brazil.

Submitted Feb. 13, 2015; Revised Apr. 7, 2015; Accepted May 8, 2015
}

(Manso et al., 2006). The lipid metabolism is highly variable in the rumen and total tract due to many factors, such as the nature and concentration of lipids in the diet, the type of chemical and/or physical treatments added to feeds, and the characteristics and the forages to concentrate ratio in the diet (Fiorentini et al., 2013).

Several types of lipids with different fatty acid composition can be used in ruminant diets (Duckett and Gillis, 2010), such as vegetable oils, oilseeds, and calcium salts of fatty acids (protected fat $[\mathrm{PF}]$ ). Therefore, it is important to evaluate their effects on intake and digestion of nutrients to achieve desired animal production.

Our hypothesis is that sources with a saturated profile (palm oil [PO]) should demonstrate a lower impact on rumen fermentation and in the flow of unsaturated fatty acids (UFA) towards the duodenum. On the one hand, 
linseed oil (LO) addition should cause disorders on the ruminal fermentation due to defaunation and negative effects of free UFA on the bacterial membrane, but on the other hand, it could to enhance the flow of UFA to be absorbed in the duodenum. Lipid diets with some types of protection and with UFA profiles (soybean and PF) would be expected to increase the flow of fatty acid through the rumen without disturbing fermentation. Thus, the objective of this study was to evaluate these lipid sources with different fatty acid profiles on nutrient digestion and ruminal fermentation in Nellore steers.

\section{MATERIALS AND METHODS}

\section{Animals and experimental feeds}

The protocol used in this experiment was in accordance with the Brazilian College of Animal Experimentation (COBEA - Colégio Brasileiro de Experimentação Animal) guidelines and was approved by the Ethics, Bioethics, and Animal Welfare Committee (CEBEA - Comissão de Ética e Bem Estar Animal) of the FCAV-UNESP-Jaboticabal campus (protocol number 012799).

Ten Nellore steers (Bos taurus indicus; $15 \pm 2$ months; 268 initial body weight $\pm 27 \mathrm{~kg}$ and 293 final body weight $\pm 27 \mathrm{~kg}$ ), fitted with ruminal and duodenal cannulas, were used for the evaluation of the DMI and nutrients digestibility, protozoa quantification, ruminal $\mathrm{pH}, \mathrm{NH}_{3}-\mathrm{N}$, volatile fatty acids (VFA), and microbial protein synthesis in a duplicated $5 \times 5$ Latin square design experiment. The experimental period lasted 100 days, and it was divided into five periods of 20 days; the first 15 days comprised a period of adaptation to the diets, and the subsequent 5 days were used for data collection. During the adaptation period, animals were kept in partially covered individual pens equipped with a drinker and feed trough. In the sampling period, they were kept in metabolism cages with a wooden slotted floor, an individual drinker and feed trough, and boxes for a total collection of feces.

The diets were calculated as described by Fiorentini et al. (2014). Five concentrates were formulated: i) without additional fat (WF; $27.9 \mathrm{~g} / \mathrm{kg}$ of ether extract [EE] in the total diet); ii) with PO derived from the palmaceae plant Orbignya oleifera, which has a lipid profile rich in lauric and myristic (medium-chain fatty acids); iii) with LO; iv) with whole soybeans (WS) - whole and unground; and v) PF (Lactoplus; Dalquim group, Itajaí, Santa Catarina, Brazil). PF (Lactoplus) is manufactured by a saponification process where fatty acids (based on soybean oil) react with calcium hydroxide. The diets LO and PO contained 45.0 $\mathrm{g} / \mathrm{kg}$ of oil, the WS diet contained $138 \mathrm{~g} / \mathrm{kg}$ of whole soybeans and the PF diet contained $51 \mathrm{~g} / \mathrm{kg}$ of Lactoplus on dry matter (DM) basis. Thus, all of the diets with added lipids contained an average of $42 \mathrm{~g}$ of additional lipid per $\mathrm{kg}$ of DM.

The proportions of ingredients and the chemical composition of the experimental diets are presented in Table 1. The roughage was corn silage $(600 \mathrm{~g} / \mathrm{kg}$ on a DM basis and with the following composition: $369 \mathrm{~g} \mathrm{DM} / \mathrm{kg}, 71 \mathrm{~g}$ crude protein $/ \mathrm{kg} \mathrm{DM}, 477 \mathrm{~g}$ neutral detergent fiber (NDF)/kg DM, 23 g EE/kg DM, and 53 g lignin/kg DM) and concentrate $(400 \mathrm{~g} / \mathrm{kg}$ on a DM basis). The concentrates were mixed weekly to restrict oxidation and rancidity of ingredients. The lipid sources (PO, LO, PF, and WS) were incorporated into the remaining ingredients of the concentrate in a horizontal mixer for $15 \mathrm{~min}$. The animals were fed with corn silage and the experimental concentrates once per day at 8:00 h. The concentrates and roughage from each animal were weighed individually and manually mixed in the troughs of each animal.

\section{Data collection and sampling procedures}

Throughout the entire experimental period, the provided quantities were adjusted to allow a surplus of approximately $100 \mathrm{~g} / \mathrm{kg}$ in relation to the total amount consumed on the previous day. Feed refusals were collected and weighed before feeding for the first 5 days of each experimental period, and subsamples were obtained and frozen at $-20^{\circ} \mathrm{C}$. Diet samples (roughage and concentrate) were collected weekly for each experimental period and frozen for subsequent chemical and nutrient evaluation. Samples of feces were collected for 5 days of each experimental period. Total fecal collection was used to determine the apparent digestibility. Representative $500 \mathrm{~g}$ of feces samples were collected at 8:00 h daily, weighed and homogenized. These samples were placed into plastic bags and frozen, and a composite sample was prepared for each animal based on the air-dry weight. Duodenal digest samples were collected as described by Fiorentini et al. (2013). Samples of feces and duodenal contents were dried in a forced-ventilation oven at $55^{\circ} \mathrm{C}$ for $72 \mathrm{~h}$ and ground in a mill with $1 \mathrm{~mm}$ mesh sieve.

Samples of feed offered, feed refusals, feces and duodenal digest were composited by treatment within period, dried at $55^{\circ} \mathrm{C}$, and ground ground in a Wiley mill (Thomas Scientific, Swedesboro, NJ, USA) to pass a one $\mathrm{mm}$ screen. Samples of corn silage, concentrates, and feed refusals were analyzed for DM (934.01), MM (942.05), and acid EE (954.02) according to AOAC (1990). The EE contents in feces and duodenal digest were determined by extraction in ether (EE; 920.39). Nitrogen was determined using a LECO FP-528 nitrogen analyzer (LECO Co., St. Joseph, MI, USA). The NDF and acid detergent fiber were determined as described by Fiorentini et al. (2014). The gross energy content of feeds and refusals was determined using an adiabatic bomb calorimeter (PARR Instrument Company 6300, Moline, IL, USA). Chemical analyses were 
Table 1. Composition of the experimental diets (g/kg DM)

\begin{tabular}{|c|c|c|c|c|c|}
\hline \multirow{2}{*}{ Items } & \multicolumn{5}{|c|}{ Diets } \\
\hline & WF & $\mathrm{PO}$ & $\mathrm{LO}$ & $\mathrm{PF}$ & WS \\
\hline \multicolumn{6}{|l|}{ Ingredient } \\
\hline Corn silage & 600 & 600 & 600 & 600 & 600 \\
\hline Ground corn & 269 & 214 & 214 & 208 & 138 \\
\hline Soybean meal & 110 & 120 & 120 & 121 & 0.00 \\
\hline Protected fat & 0.00 & 0.00 & 0.00 & 51.0 & 0.00 \\
\hline Whole soybean & 0.00 & 0.00 & 0.00 & 0.00 & 250 \\
\hline Linseed oil & 0.00 & 0.00 & 45.0 & 0.00 & 0.00 \\
\hline Palm oil & 0.00 & 45.0 & 0.00 & 0.00 & 0.00 \\
\hline Urea & 9.00 & 9.00 & 9.00 & 9.00 & 0.00 \\
\hline Mineral supplement ${ }^{1}$ & 12.0 & 12.0 & 12.0 & 12.0 & 12.0 \\
\hline \multicolumn{6}{|l|}{ Chemical composition } \\
\hline Dry matter & 562 & 569 & 568 & 563 & 563 \\
\hline Organic matter & 954 & 955 & 956 & 945 & 954 \\
\hline Crude protein & 160 & 160 & 161 & 164 & 164 \\
\hline Ether extract & 27.9 & 70.5 & 70.2 & 69.9 & 69.7 \\
\hline Neutral detergent fiber & 340 & 340 & 340 & 339 & 364 \\
\hline Acid detergent fiber & 195 & 196 & 198 & 196 & 220 \\
\hline Metabolizable energy $^{2}(\mathrm{MJ} / \mathrm{kg})$ & 10.9 & 10.7 & 10.8 & 12.2 & 11.9 \\
\hline $\mathrm{TDN}^{3}$ & 719 & 841 & 840 & 845 & 838 \\
\hline \multicolumn{6}{|c|}{ Fatty acids ( $\mathrm{g} / 100 \mathrm{~g}$ of total fatty acids) } \\
\hline C8:0 (caprylic) & 0.00 & 0.90 & 0.00 & 0.00 & 0.00 \\
\hline C10:0 (capric) & 0.00 & 1.00 & 0.00 & 0.00 & 0.00 \\
\hline C12:0 (lauric) & 0.40 & 15.70 & 0.70 & 0.30 & 0.30 \\
\hline C14:0 (myristic) & 0.40 & 5.40 & 0.50 & 0.40 & 0.40 \\
\hline C16:0 (palmitic) & 19.7 & 16.6 & 18.7 & 19.0 & 17.5 \\
\hline C16:1 (palmitoleic) & 0.10 & 0.10 & 0.10 & 0.10 & 0.10 \\
\hline C17:0 (margaric) & 0.20 & 0.20 & 0.20 & 0.20 & 0.20 \\
\hline C18:0 (stearic) & 1.90 & 0.50 & 3.80 & 0.00 & 1.30 \\
\hline C18:1 n9,c (oleic) & 30.5 & 24.6 & 28.6 & 29.9 & 27.3 \\
\hline C18:2 n6,c (linoleic) & 43.3 & 31.8 & 36.3 & 45.9 & 46.3 \\
\hline C18:3 n-3 (alpha linolenic) & 2.80 & 2.80 & 11.20 & 4.40 & 4.10 \\
\hline C20:0 (arachidic) & 0.00 & 0.00 & 0.10 & 0.00 & 2.60 \\
\hline
\end{tabular}

DM, dry matter; WF, without additional fat; PO, palm oil; LO, linseed oil; PF, protected fat (Lactoplus); WS, whole soybeans.

${ }^{1}$ Composition of product expressed in $\mathrm{g}$ or mg per $100 \mathrm{~g}$ of supplement: calcium, $4.5 \mathrm{~g}$; phosphorus, $1.2 \mathrm{~g}$; magnesium, $4.6 \mathrm{~g}$; sulfur, $1.4 \mathrm{~g}$; sodium, $5.8 \mathrm{~g}$; copper, $14 \mathrm{mg}$; manganese, $41 \mathrm{mg}$; zinc, $52.5 \mathrm{mg}$; iodine, $1 \mathrm{mg}$; cobalt, $0.8 \mathrm{mg}$; selenium, $0.3 \mathrm{mg}$; fluorine (maximun), $12 \mathrm{mg}$.

${ }^{2}$ Metabolizable energy $=$ total apparent digestibility of gross energy $\times 0.82$.

${ }^{3}$ Total digestible nutrients as described by Fiorentini et al. (2014).

performed on each sample in duplicate, and when the coefficient of variation for the replicate analysis was more than $5 \%$, the analysis was repeated.

Feed intake for each steer was calculated as the difference between the feed offered and refused during each period. Nutrient digestibilities were calculated by the following formula: [1-(output of nutrient/intake of nutrient) $\times 100$. Indigestible NDF (iNDF) was used as an indicator of daily DM flows in the duodenum (Harvatine and Allen, 2006). This fiber was obtained via an in situ methodology after 240 hours (Casali et al., 2008) with incubated samples of feed offered, feed refusals, feces and ground duodenal digest (Wiley mill, $2 \mathrm{~mm}$ screen). The
iNDF was analyzed using an Ankom Fiber Analyzer (Ankom Technology, Fairport, NY, USA). Duodenal DM flow was calculated according to the following equation (Fiorentini et al., 2013): Duodenal DM flow = [(fecal $\mathrm{DM} \times \mathrm{g} / \mathrm{kg}$ iNDF in fecal DM)/g/kg iNDF in duodenal DM].

The extraction of fatty acids was conducted as described by Fiorentini et al. (2013). Fatty acids were quantified using a GC 20-10 gas chromatograph (Shimadzu Co., Kyoto, Japan; $100 \mathrm{~m} \times 0.20 \mathrm{~mm}$ i.d. with $0.02-\mu \mathrm{m}$ film thickness; Supelco, Bellefonte, PA, USA) (Table 1). The biohydrogenation extent $(\mathrm{BH})$ was calculated as described by $\mathrm{Wu}$ et al. (1991). $\mathrm{BH}=100-100[$ (total duodenal digesta unsaturated $18 \mathrm{C} /$ total $18 \mathrm{C}$ in duodenal digesta)/(total 
unsaturated $18 \mathrm{C}$ intake/total $18 \mathrm{C}$ intake)].

To evaluate rumen fermentation parameters, rumen fluid samples (approximately $80 \mathrm{~mL}$ ) were collected manually on the last day of each experimental period, both before supplying the diet (time zero) and 1, 2, 4, 6, 8, 10, 12, and $14 \mathrm{~h}$ after feeding. The samples were filtered through double-layer cotton fabric. Immediately after collection, the $\mathrm{pH}$ of rumen fluid was determined using a digital potentiometer (ORION 710A, Boston, MA, USA). A $2 \mathrm{~mL}$ aliquot of collected fluid was placed into a plastic bottle and frozen at $-20^{\circ} \mathrm{C}$ for subsequent VFA analysis according to a method adapted from as described by Fiorentini et al. (2013). A $40 \mathrm{~mL}$ aliquot of rumen fluid was used for $\mathrm{NH}_{3}-\mathrm{N}$ analysis following the methodology adapted by Fenner (1965). On the last day of each experimental period ruminal samples (solid and liquid digest) were collected manually at 12:00 $\mathrm{h}$ for protozoa counts and analysis as described by Fiorentini et al. (2013).

Total urine was collected for 5 day each experimental period using funnel collectors attached to the animals. The funnel collector was connected to a polyethylene flexible tube, which directed the urine to containers containing 500 $\mathrm{mL}$ of $\mathrm{H}_{2} \mathrm{SO}_{4}(200 \mathrm{~mL} / \mathrm{L}$; volume/volume) to avoid loss of nitrogenous compounds. After each $24 \mathrm{~h}$ collection period, the total weight and volume of urine excreted was determined. A composite sample was made from the 5 sampling days. The composite sample was homogenized, and a $10 \mathrm{~mL}$ sub-sample was diluted with $40 \mathrm{~mL}$ of 0.018 $\mathrm{mM} \mathrm{H}_{2} \mathrm{SO}_{4}$. Microbial protein synthesis was calculated via urinary total excretion of purine derivatives (PD; allantoin+uric acid), according to Pina et al. (2009).

\section{Statistical analyses}

Data of DMI, nutrients intake, digestibility, protozoa quantification, and microbial protein synthesis were analyzed as a double $5 \times 5$ Latin square using SAS PROC MIXED 2000 (SAS Institute Inc., Cary, NC, USA). Dietary treatments were considered fixed whereas steers and periods were random variables. The general mathematical model was represented as follows:

$$
\mathrm{Y}_{i j}=\mu+\mathrm{S}_{i}+\mathrm{T}_{i}+\mathrm{P}_{j}+\mathrm{TP}_{i j}+\mathrm{e}_{i j}
$$

where $\mathrm{Y}_{i j}$ is the dependent variable; $\mu$ is the overall mean; $\mathrm{S}_{i}$ is the effect of steer $i ; \mathrm{T}_{i}$ is the $i$ th effect of the treatment or diet; $\mathrm{P}_{j}$ is the $j$ th effect of the period; $\mathrm{TP}_{i j}$ is the effect of the interaction between treatment $i$ and period $j$; and $\mathrm{e}_{i j}$ is the residual experimental error. In the statistical model, normally and independently distributed errors were assumed. Data of ruminal $\mathrm{pH}, \mathrm{NH}_{3}-\mathrm{N}$, and VFA were analyzed as double $5 \times 5$ Latin square using repeated measures according to the following model:

$$
\mathrm{Y}_{i j k l}=\mu+\mathrm{S}_{i}+\mathrm{T}_{i}+\mathrm{P} j+\mathrm{TP}_{i j}+\varepsilon_{i j k}+\mathrm{H} l+\mathrm{TH}_{k l}+\omega_{i j k l}
$$

where $\mathrm{Y}_{i j}$ is the dependent variable; $\mu$ is the overall mean; $\mathrm{S}_{i}$ is the effect of steer $i ; \mathrm{T}_{i}$ is the $i$ th effect of the treatment or diet; $\mathrm{P}_{j}$ is the $j$ th effect of the period; $\mathrm{TP}_{i j}$ is the effect of the interaction between treatment $i$ and period $j ; \varepsilon_{i j k}$ is the whole plot error; $\mathrm{H}_{l}$ is the effect of the sampling time 1; $\mathrm{TH}_{k l}$ is the interaction between treatment $k$ and sampling time $l$, and $\omega_{i j k l}$ is the split plot error.

Differences between treatment means were determined by Tukey's test. Significance was declared at $\mathrm{p}<0.05$ and trends at $0.05<\mathrm{p}<0.10$.

\section{RESULTS}

The higher intake of DM and OM was found in animals fed PF and WF $(p<0.001)$ (Table 2). Animals fed with WS had intermediate intake, whereas the diet PO had the lowest intake. The intake of DM and OM of animals fed with LO did not differ from PO and WS diets. The higher EE intake occurred in animals receiving PF $(p<0.001)$. However, animals fed PO, showed intake similar to that of animals fed WF.

The treatments with $\mathrm{PO}$ and $\mathrm{LO}$ decreased total digestibility of DM $(\mathrm{p}=0.021)$ and OM $(\mathrm{p}=0.048)$. Animals fed WF diet had lower $(\mathrm{p}<0.001)$ EE digestibility than other diets. The addition of LO resulted in the lowest NDF digestibility ( $p=0.047 ; 0.40 \mathrm{~kg} / \mathrm{kg}$ ), and the NDF digestibility was not different among the other diets. The diets PF and WF increased $N$ intake $(p=0.010)$. The higher production of microbial $\mathrm{N}(\mathrm{p}=0.030)$ was in the animals fed WF, LO, and WS, whereas animals of the PO diet had the lowest production. The higher microbial protein synthesis was found in animals on the diet with LO and WS $(p=0.040)$ (Table 2).

Diets with PO increased intake of C8:0, C10:0, C12:0, and $\mathrm{C} 14: 0$ as well as total SFA in relation to the other diets $(\mathrm{p}<0.001)$ (Table 3). The highest C18:0 and linolenic acid intake occurred in animals fed LO $(p<0.001)$, and the highest intake of oleic $(p=0.002)$ and C16 acids $(p=0.022)$ occurred with the diets with LO and PF. Diets with PF and WS promoted greater intake of linoleic acid (C18:2 n6,c), total fatty acids and total UFA $(\mathrm{p}<0.05)$.

The duodenal flow of C16:0, C18:0, oleic, elaidic $(\mathrm{C} 18: 1 n 9, t)$, linoleic $(\mathrm{C} 18: 2 n 6, c)$, linolenic, total SFA, and total UFA was affected by lipid sources $(\mathrm{p}<0.05)$ (Table 3$)$. The highest flow of SFA and C18:0 was achieved with the diets containing LO, PF, and WS. The addition of LO increased $(p=0.02)$ duodenal flow of linolenic acid. The UFA flow was higher $(\mathrm{p}=0.012)$ with the diet containing PF compared with the diets WF, PO, and WS. There were no differences for digestibility of the SFA, UFA, and total fatty acids $(\mathrm{p}>0.05)$ (Table 3$)$. The treatment with PF had 
Table 2. Effects of feeding supplemental lipid sources on nutrient intake and nutrient digestibility of Nellore steers

\begin{tabular}{|c|c|c|c|c|c|c|c|}
\hline \multirow{2}{*}{ Items } & \multicolumn{5}{|c|}{ Diets } & \multirow{2}{*}{ SEM } & \multirow{2}{*}{ p-value } \\
\hline & WF & $\mathrm{PO}$ & $\mathrm{LO}$ & $\mathrm{PF}$ & WS & & \\
\hline \multicolumn{8}{|l|}{ Intake $(\mathrm{kg} / \mathrm{d})$} \\
\hline Dry matter & $4.50^{\mathrm{a}}$ & $2.43^{\mathrm{c}}$ & $3.09^{\mathrm{bc}}$ & $4.26^{\mathrm{a}}$ & $3.36^{\mathrm{b}}$ & 0.32 & $<0.001$ \\
\hline Organic matter & $4.32^{\mathrm{a}}$ & $2.37^{\mathrm{c}}$ & $3.00^{\mathrm{bc}}$ & $4.07^{\mathrm{a}}$ & $3.25^{\mathrm{b}}$ & 0.31 & $<0.001$ \\
\hline Ether extract & $0.09^{c}$ & $0.14^{\mathrm{c}}$ & $0.23^{b}$ & $0.31^{\mathrm{a}}$ & $0.21^{\mathrm{b}}$ & 0.02 & $<0.001$ \\
\hline $\mathrm{N}$ intake & $0.12^{\mathrm{a}}$ & $0.08^{\mathrm{c}}$ & $0.08^{c}$ & $0,12^{\mathrm{a}}$ & $0,10^{\mathrm{b}}$ & 0.08 & 0.010 \\
\hline NDF & 1.52 & 1.20 & 1.11 & 1.48 & 1.26 & 0.14 & 0.117 \\
\hline \multicolumn{8}{|l|}{ Total apparent digestibility $(\mathrm{kg} / \mathrm{kg})$} \\
\hline Dry matter & $0.73^{\mathrm{a}}$ & $0.65^{\mathrm{b}}$ & $0.66^{\mathrm{b}}$ & $0.75^{\mathrm{a}}$ & $0.72^{\mathrm{a}}$ & 0.02 & 0.021 \\
\hline Organic matter & $0.71^{\mathrm{a}}$ & $0.64^{\mathrm{b}}$ & $0.65^{\mathrm{b}}$ & $0.74^{\mathrm{a}}$ & $0.71^{\mathrm{a}}$ & 0.02 & 0.048 \\
\hline Ether extract & $0.54^{\mathrm{b}}$ & $0.80^{\mathrm{a}}$ & $0.81^{\mathrm{a}}$ & $0.83^{\mathrm{a}}$ & $0.88^{\mathrm{a}}$ & 0.06 & $<0.001$ \\
\hline NDF & $0.51^{\mathrm{a}}$ & $0.48^{\mathrm{a}}$ & $0.40^{\mathrm{b}}$ & $0.56^{\mathrm{a}}$ & $0.51^{\mathrm{a}}$ & 0.06 & 0.047 \\
\hline OMDR (kg/d) & 2.05 & 1.21 & 1.49 & 2.01 & 1.52 & 0.30 & 0.247 \\
\hline Microbial N (g/d) & $43.3^{\mathrm{a}}$ & $19.7^{\mathrm{c}}$ & $51.7^{\mathrm{a}}$ & $34.0^{\mathrm{b}}$ & $47.7^{\mathrm{a}}$ & 6.70 & 0.030 \\
\hline Microbial protein synthesis (g N/kg OMDR) & $21.1^{b}$ & $16.4^{\mathrm{b}}$ & $34.6^{\mathrm{a}}$ & $16.9^{\mathrm{b}}$ & $31.4^{\mathrm{a}}$ & 5.20 & 0.040 \\
\hline
\end{tabular}

WF, without additional fat; PO, palm oil; LO, linseed oil; PF, protected fat (Lactoplus); WS, whole soybeans; SEM, standard error of the mean; NDF, neutral detergent fiber; OMDR, organic matter apparently digested in the rumen.

a,b,c Means within a row with differing superscripts differ (Tukey's test, $\mathrm{p}<0.05$ ).

lower BH of C18:1 n9,c (p=0.04), C18:2n6,c $(\mathrm{p}=0.03)$, and total UFA $(\mathrm{p}=0.044)$ (Table 3$)$ than other diets.

The diet with PF and WF increased the concentration of $\mathrm{NH}_{3}-\mathrm{N} \quad(\mathrm{p}<0.001)$ (Table 4); however, the diet did not change in VFAs $(p>0.05)$, such as the molar percentage of acetate (ACE), propionate (PROP), butyrate and the ACE:PROP ratio. There was a tendency $(p=0.06)$ to change ruminal $\mathrm{pH}$ values and total VFA $(\mathrm{p}=0.092)$ with lipid diets. The number of protozoa of the genus Entodinium and total protozoa was affected by the lipid sources $(\mathrm{p}<0.001)$ (Table 5). Treatments PO, LO and with WS decreased by around $50 \%$ the concentration of protozoa $(\mathrm{p}<0.001)$.

\section{DISCUSSION}

In this study, we evaluated the influence of several lipid sources on ruminal digestion and fermentation as well as the extent of fatty acid biohydrogenation in the rumen. The decreased DMI in diets with LO, PO, and WS was in accordance with the results found in the literature, which show that the reduction in intake with the inclusion of fatty acids may be associated with reduced digestibility, especially in the fiber fraction of the diet (Wanapat et al., 2011). A negative effect on fiber digestibility was only observed in the diet with LO compared with the diets WF and those with PF. These observations may be linked to the number of double bonds in the fatty acid molecules and to the high availability of this source, which tends to reduce cellulolytic bacteria proportion (Yang et al., 2009). Although the DMI as a percentage of BW can be considered low for WF and PF, these values corroborated with
Fiorentini et al. (2014), who worked with the same diets in a performance trial.

The intake and digestibility reduction in the PO diets rich in SFA with the same intensity as sources rich in UFA (LO and WS) was not expected, and these results differed from the discussions about the low disturbance of SFA supplementation on the ruminal environment, and consequently the reduction of negative effects on the fiber digestibility (Wanapat et al., 2011). According to Sullivan et al. (2004), diets containing more than $70 \mathrm{~g} / \mathrm{kg}$ EE in the DM can impair feed degradation, especially if there is a high proportion of UFA, which had greater impact on rumen fermentation than SFA due to many factors, such as fiber coating, toxic effect to Gram-positive bacteria and protozoa (Soliva et al., 2004), and modifying hydrogen uptake by methanogens. It is likely that in addition to the SFA profiles of PO, other dietary factors, such as the low acceptance by animals and a possible toxicity effect of this lipid source, can be linked to the intake and digestibility reduction. Similarly, Otaru et al. (2011) verified a decreasing linear effect on DMI in goats fed diets with PO. Once the level of lipid addition is variable and dependent of the particular source of fatty acids used, type of animal, and method of lipid processing, there is no optimum level of lipid that can be added in the ruminant diet.

The increased EE digestibility in diets with lipid addition was consistent with the results of Manso et al. (2006). The higher digestibility coefficients in lipidsupplemented animals can be attributed the fact that nonfatty acids lipids in the diet (likely approximately $1 \%$ of DM) are relatively indigestible, and diluting this fraction (waxes, etc.) with more fatty acids increases the 
Table 3. Effects of feeding supplemental lipid sources on intake and flow of the fatty acids of Nellore steers

\begin{tabular}{|c|c|c|c|c|c|c|c|}
\hline \multirow{2}{*}{ Items } & \multicolumn{5}{|c|}{ Diets } & \multirow{2}{*}{ SEM } & \multirow{2}{*}{ p-value } \\
\hline & WF & $\mathrm{PO}$ & $\mathrm{LO}$ & $\mathrm{PF}$ & WS & & \\
\hline \multicolumn{8}{|l|}{ Fatty acid intake (g/d) } \\
\hline C8:0 (caprylic) & $0.01^{\mathrm{b}}$ & $4.08^{\mathrm{a}}$ & $0.01^{\mathrm{b}}$ & $0.01^{\mathrm{b}}$ & $0.01^{\mathrm{b}}$ & 0.21 & $<0.001$ \\
\hline C10:0 (capric) & $0.01^{\mathrm{b}}$ & $4.80^{\mathrm{a}}$ & $0.01^{\mathrm{b}}$ & $0.01^{\mathrm{b}}$ & $0.01^{\mathrm{b}}$ & 0.23 & $<0.001$ \\
\hline C12:0 (lauric) & $0.16^{\mathrm{b}}$ & $71.3^{\mathrm{a}}$ & $1.16^{\mathrm{b}}$ & $0.07^{\mathrm{b}}$ & $0.27^{\mathrm{b}}$ & 3.81 & $<0.001$ \\
\hline C14:0 (myristic) & $0.28^{\mathrm{b}}$ & $22.9^{\mathrm{a}}$ & $0.54^{\mathrm{b}}$ & $0.10^{\mathrm{b}}$ & $0.20^{\mathrm{b}}$ & 1.29 & $<0.001$ \\
\hline C16:0 (palmitic) & $16.6^{\mathrm{b}}$ & $26.5^{\mathrm{b}}$ & $44.1^{\mathrm{a}}$ & $33.4^{\mathrm{a}}$ & $30.3^{b}$ & 5.88 & 0.022 \\
\hline C18:0 (stearic) & $0.72^{\mathrm{b}}$ & $0.01^{\mathrm{b}}$ & $13.10^{\mathrm{a}}$ & $0.01^{\mathrm{b}}$ & $2.03^{b}$ & 1.40 & $<0.001$ \\
\hline C18:1 $n 9, c$ (oleic) & $21.1^{\mathrm{b}}$ & $48.6^{\mathrm{b}}$ & $73.7^{\mathrm{a}}$ & $78.6^{\mathrm{a}}$ & $56.8^{\mathrm{b}}$ & 10.1 & 0.002 \\
\hline C18:2 $n 6, c$ (linoleic) & $87.1^{\mathrm{b}}$ & $79.1^{\mathrm{b}}$ & $99.5^{\mathrm{b}}$ & $220^{\mathrm{a}}$ & $201^{\mathrm{a}}$ & 10.7 & $<0.001$ \\
\hline C18:3 n-3 (alpha linolenic) & $1.35^{\mathrm{b}}$ & $2.44^{\mathrm{b}}$ & $52.1^{\mathrm{a}}$ & $15.8^{\mathrm{b}}$ & $5.62^{\mathrm{b}}$ & 5.42 & $<0.001$ \\
\hline C20:0 (arachidic) & $0.01^{\mathrm{b}}$ & $0.01^{\mathrm{b}}$ & $0.01^{\mathrm{b}}$ & $0.01^{\mathrm{b}}$ & $20.9^{\mathrm{a}}$ & 0.48 & $<0.001$ \\
\hline Total intake & $126^{\mathrm{c}}$ & $260^{\mathrm{b}}$ & $285^{\mathrm{b}}$ & $348^{\mathrm{a}}$ & $318^{\mathrm{a}}$ & 23.40 & $<0.001$ \\
\hline SFA $^{1}$ & $17.4^{\mathrm{c}}$ & $130.2^{\mathrm{a}}$ & $59.9^{\mathrm{b}}$ & $33.7^{\mathrm{c}}$ & $54.4^{\mathrm{b}}$ & 8.75 & $<0.001$ \\
\hline $\mathrm{UFA}^{2}$ & $109^{c}$ & $130^{c}$ & $225^{\mathrm{b}}$ & $315^{\mathrm{a}}$ & $273^{\mathrm{a}}$ & 17.30 & $<0.001$ \\
\hline \multicolumn{8}{|l|}{ Flow to duodenum (g/d) } \\
\hline C10:0 (capric) & 0.71 & 4.27 & 1.99 & 3.66 & 3.36 & 1.90 & 0.590 \\
\hline C12:0 (lauric) & 1.71 & 7.20 & 3.99 & 7.19 & 2.79 & 1.87 & 0.080 \\
\hline C14:0 (myristic) & 0.71 & 0.31 & 1.02 & 1.38 & 0.35 & 0.40 & 0.230 \\
\hline C16:0 (palmitic) & $25.5^{\mathrm{b}}$ & $21.2^{\mathrm{b}}$ & $35.7^{\mathrm{b}}$ & $67.3^{\mathrm{a}}$ & $32.4^{b}$ & 9.88 & 0.011 \\
\hline C18:0 (stearic) & $96.3^{\mathrm{b}}$ & $60.0^{\mathrm{b}}$ & $138^{\mathrm{a}}$ & $129^{\mathrm{a}}$ & $165^{\mathrm{a}}$ & 28.50 & 0.042 \\
\hline C18:1 $n 9, c$ (oleic) & $10.4^{\mathrm{ab}}$ & $5.96^{\mathrm{b}}$ & $22.7^{\mathrm{ab}}$ & $34.5^{\mathrm{a}}$ & $13.2^{\mathrm{ab}}$ & 4.02 & 0.011 \\
\hline C18:1 $n 9, t$ (elaidic) & $3.77^{\mathrm{b}}$ & $2.17^{\mathrm{b}}$ & $12.90^{\mathrm{ab}}$ & $21.50^{\mathrm{a}}$ & $1.75^{\mathrm{b}}$ & 6.51 & 0.022 \\
\hline C18:2 $n 6, c$ (linoleic) & $4.10^{\mathrm{ab}}$ & $1.48^{\mathrm{b}}$ & $2.33^{\mathrm{ab}}$ & $7.58^{\mathrm{ab}}$ & $9.32^{\mathrm{a}}$ & 2.01 & 0.020 \\
\hline C18:3 n3 (alpha linolenic) & $0.24^{\mathrm{c}}$ & $0.15^{\mathrm{c}}$ & $1.17^{\mathrm{a}}$ & $0.68^{\mathrm{b}}$ & $0.65^{b}$ & 0.29 & 0.292 \\
\hline C20:0 (arachidic) & 1.08 & 0.75 & 0.82 & 5.72 & 1.92 & 1.99 & 0.041 \\
\hline SFA $^{1}$ & $126^{\mathrm{b}}$ & $94.6^{\mathrm{b}}$ & $183^{\mathrm{a}}$ & $217^{\mathrm{a}}$ & $206^{\mathrm{a}}$ & 35.10 & 0.043 \\
\hline $\mathrm{UFA}^{2}$ & $18.8^{\mathrm{b}}$ & $9.70^{\mathrm{b}}$ & $39.9^{\mathrm{ab}}$ & $65.2^{\mathrm{a}}$ & $25.5^{\mathrm{b}}$ & 9.91 & 0.012 \\
\hline \multicolumn{8}{|l|}{ Total digestibility $(\mathrm{kg} / \mathrm{kg}$ ) } \\
\hline Total fatty acids & 0.86 & 0.89 & 0.84 & 0.89 & 0.91 & 0.04 & 0.620 \\
\hline SFA $^{1}$ & 0.70 & 0.88 & 0.80 & 0.62 & 0.81 & 0.11 & 0.351 \\
\hline $\mathrm{UFA}^{2}$ & 0.87 & 0.88 & 0.86 & 0.93 & 0.93 & 0.04 & 0.292 \\
\hline \multicolumn{8}{|c|}{ Ruminal biohydrogenation extent (\%) } \\
\hline C18:1 $n 9, c(\text { oleic })^{3}$ & $73.9^{\mathrm{a}}$ & $73.0^{\mathrm{a}}$ & $71.0^{\mathrm{a}}$ & $58.6^{\mathrm{b}}$ & $72.7^{\mathrm{a}}$ & 5.34 & 0.040 \\
\hline C18:2 $n 6, c$ (linoleic) $^{3}$ & $94.9^{\mathrm{a}}$ & $96.5^{\mathrm{a}}$ & $97.8^{\mathrm{a}}$ & $89.9^{\mathrm{b}}$ & $94.1^{\mathrm{a}}$ & 1.58 & 0.030 \\
\hline C18:3 n3 (alpha linolenic) ${ }^{3}$ & 85.9 & 86.7 & 89.8 & 91.4 & 91.5 & 6.56 & 0.110 \\
\hline $\mathrm{BH}_{\text {total }} \mathrm{UFA}^{4}$ & $87.3^{\mathrm{a}}$ & $89.1^{\mathrm{a}}$ & $84.6^{\mathrm{a}}$ & $76.7^{b}$ & $89.1^{\mathrm{a}}$ & 2.68 & 0.044 \\
\hline
\end{tabular}

WF, without additional fat; PO, palm oil; LO, linseed oil; PF, protected fat (Lactoplus); WS, whole soybeans; SEM, standard error of the mean; SFA, saturated fatty acids; UFA, unsaturated fatty acids.

${ }^{1} \mathrm{SFA}=\mathrm{C} 4: 0$; C6:0; C8:0; C10:0; C12:0; C13:0iso; C13:0ant; C14:0iso; C14:0; C15:0iso; C15:0ant; C14:1c9; C15:0; C16:0iso; C16:0; C17:0iso; C17:0; $\mathrm{C} 18: 0 ; \mathrm{C} 20: 0 ; \mathrm{C} 22: 0 ; \mathrm{C} 24: 0$.

${ }^{2} \mathrm{UFA}=\mathrm{C} 16: 1 c 9 ; \mathrm{C} 17: 1 ; \mathrm{C} 18: 1 t 6 ; \mathrm{C} 18: 1 t 9 ; \mathrm{C} 18: 1 t 10 ; \mathrm{C} 18: 1 t 11 ; \mathrm{C} 18: 1 t 12 ; \mathrm{C} 18: 1 c 9 ; \mathrm{C} 18: 1 c 11 ; \mathrm{C} 18: 1 c 12 ; \mathrm{C} 18: 1 c 13 ; \mathrm{C} 18: 1 t 16 ; \mathrm{C} 18: 1 c 15 ;$ $\mathrm{C} 18: 2 t 11 c 15 ; \mathrm{C} 18: 2 c 9 c 12 ; \mathrm{C} 18: 3 ; \mathrm{C} 18: 2 c 9 t 11 ; \mathrm{C} 20: 1 ; \mathrm{C} 24: 1 ; \mathrm{C} 20: 3 ; \mathrm{C} 20: 4 ; \mathrm{C} 20: 5 ; \mathrm{C} 22: 1 ; \mathrm{C} 22: 2 ; \mathrm{C} 22: 5 ; \mathrm{C} 22: 6 ; \mathrm{C} 24: 1$.

${ }^{3}$ Individual $18-\mathrm{C}$ unsaturated fatty acid biohydrogenation, $\%=100-\{100 \times($ individual $18-\mathrm{C}$ UFA/total $18-\mathrm{C}$ in duodenal digesta)/(individual $18-\mathrm{C}$ UFA/total 18-C intake)\}.

${ }^{4}$ Biohydrogenation of total unsaturated C18 fatty acids $=100-100 \times\{($ TDDUC18/TC18DD $)\} /\{($ TUC18I/TC18I $)\} ;$ where, TDDUC18 $=$ total duodenal digesta unsaturated $\mathrm{C} 18$; TC18DD $=$ total $\mathrm{C} 18$ in duodenal digesta; $\mathrm{TUC18 \textrm {I }}=$ total unsaturated $\mathrm{C} 18$ intake; $\mathrm{TC} 18 \mathrm{I}=$ total $\mathrm{C} 18$ intake.

${ }^{\mathrm{a}, \mathrm{b}, \mathrm{c}}$ Means within a row with differing superscripts differ (Tukey's test, $\mathrm{p}<0.05$ ).

digestibility of the EE fraction.

The flow of fatty acids in the present study indicated the disappearance and modification of fatty acids in the rumen. According to Doreau and Ferlay (1994) and Schmidely et al.
(2008), the negative balance of fatty acids (consumed/recovered in the duodenum) is frequent, especially in diets rich in lipids (more than $5 \%$ of fatty acids in the dietary DM). The disappearance of fatty acids in the 
Table 4. Effects of feeding supplemental lipid sources on ruminal fermentation of Nellore steers

\begin{tabular}{|c|c|c|c|c|c|c|c|c|c|}
\hline \multirow{2}{*}{ Items } & \multicolumn{5}{|c|}{ Diets } & \multirow{2}{*}{ SEM } & \multicolumn{3}{|c|}{ p-value } \\
\hline & WF & $\mathrm{PO}$ & LO & $\mathrm{PF}$ & WS & & Diet & Time & Diet $\times$ time \\
\hline $\mathrm{NH}_{3}-\mathrm{N}(\mathrm{mg} / \mathrm{dL})$ & $16.6^{\mathrm{a}}$ & $7.09^{\mathrm{b}}$ & $7.33^{b}$ & $13.9^{\mathrm{a}}$ & $9.28^{\mathrm{b}}$ & 1.39 & $<0.001$ & $<0.001$ & 0.102 \\
\hline $\mathrm{pH}$ & 6.21 & 6.37 & 6.51 & 6.24 & 6.32 & 0.08 & 0.065 & $<0.001$ & 0.567 \\
\hline Total VFA $(\mathrm{mmol} / \mathrm{L})$ & 90.3 & 72.6 & 78.3 & 92.6 & 79.5 & 8.21 & 0.092 & 0.012 & 0.329 \\
\hline \multicolumn{10}{|l|}{ VFAs $(\%)$} \\
\hline $\mathrm{ACE}$ & 66.9 & 65.2 & 64.3 & 67.0 & 63.5 & 2.10 & 0.631 & $<0.001$ & 0.197 \\
\hline PROP & 20.9 & 23.1 & 25.1 & 21.1 & 25.5 & 1.93 & 0.198 & $<0.001$ & 0.263 \\
\hline Butyrate & 12.2 & 11.7 & 10.6 & 11.9 & 11.0 & 0.83 & 0.568 & $<0.001$ & 0.556 \\
\hline ACE:PROP ratio & 3.20 & 2.82 & 2.56 & 3.17 & 2.49 & 0.29 & 0.325 & $<0.001$ & 0.681 \\
\hline
\end{tabular}

WF, without additional fat; PO, palm oil; LO, linseed oil; PF, protected fat (Lactoplus); WS, whole soybeans; SEM, standard error of the mean; VFA, volatile fatty acid; ACE, acetate; PROP, propionate.

${ }^{\mathrm{a}, \mathrm{b}}$ Means within a row with differing superscripts differ (Tukey's test, $\mathrm{p}<0.05$ ).

rumen can be attributed to the following factors: i) absorption of fatty acids in the rumen as the amount of lipids in the diet increases; ii) catabolization of fatty acids in ketone bodies in the cells of the ruminal epithelium; and iii) oxidation of fatty acids by bacteria adherent to the rumen wall, which utilize oxygen from epithelial cells (Doreau and Ferlay, 1994). However, it is not possible to associate these effects with characteristics of the supplemental fat, e.g., protection or degree of saturation (Doreau and Ferlay, 1994). Thus, with the aim of evaluating ruminal biohydrogenation, Schmidely et al. (2008) worked in a meta-analysis (95 experiments and 303 treatments) and they estimated an average recovery of $75 \%$ of the fatty acids of the duodenum, thereby corroborating with current data. Sterk et al. (2012) reported low duodenal recovery of fatty acids in dairy cows diets with lipid addition of 55 to $65 \mathrm{~g} / \mathrm{kg}$ DM.

The results of UFA and SFA flow indicated the effect of ruminal biohydrogenation, which is the passage of lipids of dietary and microbial origins into the duodenum (Jenkins, 1994). In fact, a greater quantity of C18:1 $n 9, t$ (elaidic acid), an intermediate product of biohydrogenation, was observed. These results are similar to those reported by Menezes et al. (2010) in crossbred steers (Charolais $\times$ Nellore) fed with $60 \%$ of corn silage and $40 \%$ of concentrate. The high ruminal outflow of SFA, especially C18:0, in animals fed diets with LO, PF, and WS may be explained by higher intake of oleic and linoleic acids in these treatments, which are SFA to C18:0 by rumen microorganisms through ruminal biohydrogenation (Duckett and Gillis, 2010). Both intake and presence of conjugated linoleic acid in duodenal digest were virtually nil in all treatments and these results corroborate with Menezes et al. (2010).

In an extensive review Doreau and Ferlay (1994) reported ruminal $\mathrm{BH}$ of linolenic averaged $92 \%$ (range, $85 \%$ to $100 \%$ ) and $\mathrm{BH}$ of linoleic averaged $80 \%$ (range, $70 \%$ to $95 \%$ ). The present ruminal $\mathrm{BH}$ was close to the range reported by Doreau and Ferlay (1994) for linolenic (range, $85.9 \%$ to $91.5 \%$ ) and linoleic (range, $89.9 \%$ to $97.8 \%$ ). As BH of oleic, the results found in this study were higher than those reported by $\mathrm{Wu}$ et al. (1991), who found values of the 44.2 in diets with $6 \%$ of PF. The $\mathrm{BH}$ total of UFA was lower in animals fed the diet with PF because calcium soaps in the rumen are not dissociated, thus delaying biohydrogenation by bacteria (Harvatine and Allen, 2006) and allowing UFA absorption in the duodenum and meat deposition. Our results were in accordance with previous literature reporting partial dissociation of calcium salts of soybean oil. Klusmeyer and Clark (1991) reported $50 \%$ protection with soybean against ruminal biohydrogenation calcium salts of soybean fatty acid. Similarly, Lundy et al. (2004) studied the addition of $2.75 \%$ soybean oil calcium salts in the diet of dairy cows, and they found biohydrogenation values of 77.9 and $92.2 \%$ for $18: 1$ (n9) and 18:2 (n3) acids, respectively. According to Jenkins and Bridges Jr. (2007), PF provide inconsistent results with limited ruminal protection. However, the PF could be

Table 5. Effects of feeding supplemental lipid sources on the population of ciliated protozoa in the rumen of Nellore steers

\begin{tabular}{|c|c|c|c|c|c|c|c|}
\hline & \multicolumn{5}{|c|}{ Diets } & \multirow{2}{*}{ SEM } & \multirow{2}{*}{ p-value } \\
\hline & WF & $\mathrm{PO}$ & $\mathrm{LO}$ & $\mathrm{PF}$ & WS & & \\
\hline \multicolumn{8}{|c|}{ Protozoa $\left(\mathrm{n}^{\circ} \times 10^{5} / \mathrm{mL}\right)$} \\
\hline Entodinium & $25.6^{\mathrm{a}}$ & $7.90^{\mathrm{b}}$ & $2.21^{\mathrm{b}}$ & $22.3^{\mathrm{a}}$ & $2.24^{\mathrm{b}}$ & 4.31 & $<0.001$ \\
\hline Epidinium & 0.03 & 0.00 & 0.00 & 0.00 & 0.00 & 0.02 & 0.476 \\
\hline Diplodininae & 0.70 & 0.02 & 0.02 & 1.28 & 0.01 & 0.12 & 0.342 \\
\hline Total & $26.3^{\mathrm{a}}$ & $7.92^{\mathrm{b}}$ & $2.23^{b}$ & $23.6^{\mathrm{a}}$ & $2.25^{\mathrm{b}}$ & 4.39 & $<0.001$ \\
\hline
\end{tabular}

WF, without additional fat; PO, palm oil; LO, linseed oil; PF, protected fat (Lactoplus); WS, whole soybeans; SEM, standard error of the mean .

${ }^{a, b}$ Means within a row with differing superscripts differ (Tukey's test, $\mathrm{p}<0.05$ ). 
advantageous over non-protected because of the higher amount of UFA in the rumen that can be harmful to microbial membranes and cause metabolic disorders, mainly in cellulolytic flora (Maia et al., 2007) or decreasing fiber digestibility.

We hypothesized that diet with the PF would have higher ruminal protection. This prediction was supported by our results, showing that $\mathrm{PF}$ has a variable dissociation in the rumen, which may increase $\mathrm{BH}$ total UFA. The PF utilized in this study originated from soybean oil rich in UFA. According to Jenkins and Bridges Jr. (2007), calcium salts with a high content of SFA are more efficiently protected than those with a low content of SFA. The dramatic reductions in the feed intake with LO, PO, and WS diets could have occurred due to a slower rate of passage and increase of ruminal feed retention time, which could also contribute to a higher BH total UFA. Nevertheless it is important to highlight the increase of linolenic acid flow in the LO diets with potential improvements in the UFA composition of the meat.

In the LO and PO diets with reduced OM content and possible reduction of feed fermentability, a lower concentration of VFA was expected (Harvatine and Allen, 2006). However, our results corroborated with studies in which a small or no effect on ruminal VFA concentration was observed with the addition of lipid sources to diets for ruminants (Fiorentini et al., 2013). Diets with vegetable oils cause higher variability on $\mathrm{pH}$ (Ivan et al., 2001), due to high levels of free UFA and are more susceptible to hydrolysis by rumen bacteria than diets containing calcium salts (Wu et al., 1991) and oilseeds (Ueda et al., 2003). On the other hand, these results may suggest that rumen ecology of Nellore steers could resist specific carbohydrate addition, or can increase the absorption of VFAs.

The decrease of ruminal $\mathrm{NH}_{3}-\mathrm{N}$ concentration with vegetable oil could have occurred due to protozoa action by reducing deaminating bacteria (Doreau and Ferlay, 1995). The higher $\mathrm{NH}_{3}-\mathrm{N}$ content in the WF and PF diets may be associated with a predominance of proteolytic protozoa that engulf the rumen bacteria and release $\mathrm{NH}_{3}-\mathrm{N}$ into the rumen environment (Doreau and Ferlay, 1995). In this scenario, even with increased nitrogen intake of the animals, the incorporation of $\mathrm{NH}_{3}-\mathrm{N}$ by rumen bacteria may be reduced, and the microbial protein synthesis may be compromised (Yang et al., 2009). The concentration of $\mathrm{NH}_{3}-\mathrm{N}$ in the rumen is a consequence of the balance between its production, absorption and utilization by microorganisms. The utilization efficiency of ammonia by the microorganisms for the microbial protein synthesis depends, among other factors, on the availability of energy in the rumen, thus withstanding greater microbial growth (Russell et al., 1992).

The reduction in the number of protozoa and the amount of $\mathrm{NH}_{3}-\mathrm{N}$ in the PO, LO, and WS diets may be linked to similar negative effects of UFA in the bacterial membrane (Maia et al., 2007). In spite of the significant level of saturation, PO reduced the population of protozoa and was not sufficient enough to increase the microbial protein synthesis. The decreased concentration of rumen $\mathrm{NH}_{3}-\mathrm{N}$ and the reduced number of rumen protozoa corroborated the results reported by Eugène et al. (2004) with defaunated animals.

The supply of vegetable oils frequently increases the microbial protein synthesis (Messana et al., 2013). However, the effect of vegetable oils on microbial synthesis is not mediated by an increase in the fermentable energy content of the rumen. Vegetable oils reduce predation due to the defaunation effect of the oil (Fiorentini et al., 2013). The reduction or elimination of protozoa could be associated with microbial protein synthesis, as protozoa engulf bacteria, but because of protozoa phagocytosis starch particles, this reduction would be associated with a possible reduction in the rumen ammonia concentration and a smaller and more variable $\mathrm{pH}$ (Ivan et al., 2001), therefore decreasing carbohydrate fermentation and maintaining a consistent $\mathrm{pH}$.

\section{CONCLUSION}

Diets with some type of protection (PF and WS) decreased the effects of lipid on ruminal fermentation and presented similar outflow of benefit UFA as LO. However the PO diet impaired ruminal function parameters without contributing effectively in providing UFA into the duodenum of beef cattle.

\section{CONFLICT OF INTEREST}

We certify that there is no conflict of interest with any financial organization regarding the material discussed in the manuscript.

\section{ACKNOWLEDGMENTS}

We thank the São Paulo Research Foundation (FAPESP) (grants \#2009/ 51215-1; 2009/ 06472-6 and 2013/ 02418-2) and Bellman Nutrição Animal for providing financial support.

\section{REFERENCES}

AOAC. 1990. Official Methods of Analysis. 15th. ed. Association of Official Analytical Chemists, Arlington, VA, USA.

Casali, A. O., E. Detmann, S. C. Valadares Filho, J. C. Pereira, L. T. Henriques, S. G. Freitas, and M. F. Paulino. 2008. Influence of incubation time and particles size on indigestible compounds contents in cattle feeds and feces obtained by in situ procedures. R. Bras. Zoot. 37:335-342. 
Doreau, M. and A. Ferlay. 1994. Digestion and utilization of fatty acids by ruminants. Anim. Feed Sci. Technol. 45:379-396.

Doreau, M. and A. Ferlay. 1995. Effect of dietary lipids on nitrogen metabolism in the rumen: a review. Livest. Product. Sci. 43:97-110.

Duckett, S. K. and M. H. Gillis. 2010. Effects of oil source and fish oil addition on ruminal biohydrogenation of fatty acids and conjugated linoleic acid formation in beef steers fed finishing diets. J. Anim. Sci. 88:2684-2691.

Eugène, M., H. Archimède, and D. Sauvant. 2004. Quantitative meta-analysis on the effects of defaunation of the rumen on growth, intake and digestion in ruminants. Livest. Prod. Sci. 85:81-97.

Fenner, H. 1965. Method for determining total volatile bases in rumen fluid by steam distillation. J. Dairy Sci. 48:249-251.

Fiorentini, G., J. D. Messana, P. H. Dian, R. A. Reis, R. C. Canesin, A. V. Pires, and T. T. Berchielli. 2013. Digestibility, fermentation and rumen microbiota of crossbred heifers fed diets with different soybean oil availabilities in the rumen. Anim. Feed Sci. Technol. 181:26-34.

Fiorentini, G., I. P. Carvalho, J. D. Messana, P. S. Castagnino, A. Berndt, R. C. Canesin, R. T. Frighetto, and T. T. Berchielli. 2014. Effect of lipid sources with different fatty acid profiles on the intake, performance, and methane emissions of feedlot Nellore steers. J. Anim. Sci. 92:1613-1620.

Harvatine, K. J. and M. S. Allen. 2006. Effects of fatty acid supplements on ruminal and total tract nutrient digestion in lactating dairy cows. J. Dairy Sci. 89:1092-1103.

Ivan, M., P. S. Mir, K. M. Koenig, L. M. Rode, L. Neill, T. Entz, and Z. Mir. 2001. Effects of dietary sunflower seed oil on rumen protozoa population and tissue concentration of conjugated linoleic acid in sheep. Small Rumin. Res. 41:215227.

Jenkins, T. C. 1994. Regulation of lipid metabolism in the rumen. J. Nutr. 124(8 Suppl):1372S-1376G.

Jenkins, T. C. and W. C. Bridges Jr. 2007. Protection of fatty acids against ruminal biohydrogenation in cattle. Eur. J. Lipid Sci. Technol. 109:778-789.

Klusmeyer, T. H. and J. K. Clark. 1991. Effects of dietary fat and protein on fatty acid flow to the duodenum and in milk produced by dairy cows. J. Dairy Sci. 74:3055-3067.

Lundy, F. P., E. Block, W. C. Bridges Jr., J. A. Bertrand, and T. C. Jenkins. 2004. Ruminal biohydrogenation in Holstein cows fed soybean fatty acids as amides or calcium salts. J. Dairy Sci. 87:1038-1046.

Maia, M. R., L. C. Chaudhary, L. Figueres, and R. J. Wallace. 2007. Metabolism of polyunsaturated fatty acids and their toxicity to the microflora of the rumen. Antonie Van Leeuwenhoek 91:303-314.

Manso, T., T. Castro, A. R. Mantecón, and V. Jimeno. 2006. Effects of palm oil and calcium soaps of palm oil fatty acids in fattening diets on digestibility, performance and chemical body composition of lambs. Anim. Feed Sci. Technol. 127:175-186.
Menezes, L. F., G. V. Kozloski, J. Restle, I. L. Brondani, R. D. Pazdiora, and J. Cattelam. 2010. Profile of ingested fatty acids and in the duodenal digest of steers fed different diets. R. Bras. Zootec. 39:2502-2511.

Messana, J. D., T. T. Berchielli, P. B. Arcuri, R. A. Reis, R. C. Canesin, A. F. Ribeiro, G. Fiorentini, and J. J. Fernandes. 2013. Rumen fermentation and rumen microbes in Nellore steers receiving diets with different lipid contents. R. Bras. Zoot. 42:204-212.

Otaru, S. M., A. M. Adamu, O. W. Ehoche, and H. J. Makun. 2011. Effects of varying the level of palm oil on feed intake, milk yield and composition and postpartum weight changes of Red Sokoto goats. Small Rumin. Res. 96:25-35.

Pina, D. S., S. C. Valadares Filho, L. O. Tedeschi, A. M. Barbosa, and R. F. Valadares. 2009. Influence of different levels of concentrate and ruminally undegraded protein on digestive variables in beef heifers. J. Anim. Sci. 87:1058-1067.

Russell, J. B., J. D. O'Connor, D. G. Fox, P. J. van Soest, and C. J. Sniffen. 1992. A net carbohydrate and protein system for evaluating cattle diets: I. Ruminal fermentation. J. Anim. Sci. 70:3551-3561.

Schmidely, P., F. Glasser, M. Doreau, and D. Sauvant. 2008. Digestion of fatty acids in ruminants: a meta-analysis of flows and variation factors. 1. Total fatty acids. Animal 2:677-690.

Soliva, C. R., L. Meile, A. Cieślak, M. Kreuzer, and A. Machmüller. 2004. Rumen simulation technique study on the interactions of dietary lauric and myristic acid supplementation in suppressing ruminal methanogenesis. Br. J. Nutr. 92:689700

Sterk, A., B. Vlaeminck, A. M. van Vuuren, W. H. Hendriks, and J. Dijkstra. 2012. Effects of feeding different linseed sources on omasal fatty acid flows and fatty acid profiles of plasma and milk fat in lactating dairy cows. J. Dairy Sci. 95:3149-3165.

Sullivan, H. M., J. K. Bernard, H. E. Amos, and T. C. Jenkins. 2004. Performance of lactating dairy cows fed whole cottonseed with elevated concentrations of free fatty acids in the oil. J. Dairy Sci. 87:665-671.

Ueda, K., A. Ferlay, J. Chabrot, J. J. Loor, Y. Chilliard, and M. Doreau. 2003. Effect of linseed oil supplementation on ruminal digestion in dairy cows fed diets with different forage:concentrate ratios. J. Dairy Sci. 86:3999-4007.

Wanapat, M., C. Mapato, R. Pilajun, and W. Toburan. 2011. Effects of vegetable oil supplementation on feed intake, rumen fermentation, growth performance, and carcass characteristic of growing swamp buffaloes. Livest. Prod. Sci. 135:32-37.

Wu, Z., O. A. Ohajuruka, and D. L. Palmquist. 1991. Ruminal synthesis, biohydrogenation, and digestibility of fatty acids by dairy cows. J. Dairy Sci. 74:3025-3034.

Yang, S. L., D. P. Bu, J. Q. Wang, Z. Y. Hu, D. Li, H. Y. Wei, L. Y. Zhou, and J. J. Loor. 2009. Soybean oil and linseed oil supplementation affect profiles of ruminal microorganisms in dairy cows. Animal 3:1562-1569. 